\title{
Disillusionment and Dismay: How Chinese Netizens Think and Feel About the Two Koreas
}

\author{
Peter Gries
}

The deterioration of Sino-South Korean relations following the attacks on the Cheonan and on Yonpyong Island in 2010 has again raised the question of Chinese intentions in the Korean peninsula. In this article, I explore Chinese netizen views of the two Koreas. Qualitative and quantitative evidence (in the form of a large-scale national Internet survey) provide convergent evidence that while Chinese netizens feel coolly toward both Koreas, they think and feel about them in very different ways. Chinese netizens appear to be profoundly disillusioned with a North Korea that refuses to adopt Chinese-style "reform and opening," which only reminds them of their poor and authoritarian past. However, recent high-profile historical and cultural disputes appear to have led to widespread Chinese dismay and even anger toward South Korea as well, which is perceived to be poaching on China's proud cultural heritage. These attitudes toward Korea are reflective of evolving Chinese understandings of what it means to be Chinese in the twenty-first century. KEYwORDs: Sino-Korean relations, Chinese netizens, popular opinion, Chinese nationalism

IN 2010, A SERIES OF EVENTS ON THE KOREAN PENINSULA RAISED NEW questions about the foreign policies of the People's Republic of China (PRC) toward the two Koreas. On March 26, 2010, the Cheonan, a South Korean Navy corvette, sank in the Yellow Sea after being torn in half by an underwater explosion. Forty-six crew members were killed. Adding insult to injury, Beijing refused to acknowledge Pyongyang's culpability for the North Korean torpedo attack and did not issue its official condolences to South Korea until five weeks after the sinking. Then, on November 23, 2010, North Korea shelled Yonpyong Island, killing two South Korean civilians and two Republic of Korea (ROK) marines. Beijing was again noncommittal, with Chinese state television stating only that the two Koreas fired at one another and that South Korea fired first. 
The military aggression of the Democratic People's Republic of Korea (DPRK) is probably best explained by the leadership transition in Pyongyang. And China's policy response was likely driven by "traditionalists" within the International Liaison Department of the Chinese Communist Party, and conservatives within the People's Liberation Army (International Crisis Group 2011). But China's 2010 behavior was deeply alarming to South Koreans expecting that increasing PRC-ROK economic interdependence and interpersonal interactions would lead to improved bilateral relations. From the perspective of material self-interest, recent Chinese behavior toward the Korean peninsula has been puzzling. China clearly has much more to gain materially from its relationship with the South, and North Korean behaviors consistently undermine Chinese efforts to present themselves internationally as a responsible and benign power. China has nonetheless tended to side with the North. How can we understand this Chinese behavior?

I propose in this article that understanding Chinese policies toward the Korean peninsula requires supplementing assessments of China's rational self-interest and speculations about elite Chinese politics with an exploration of the identity politics at stake. To do so, I explore Chinese netizen views of the two Koreas. There is no way to directly assess the views of China's policymaking elite toward the two Koreas. The views of China's netizens, however, can be studied and are worth studying: they provide a window into how Chinese society more broadly views the two Koreas, as well as the ways that elite Chinese policymakers, who after all are Chinese too, likely think and feel about the Koreas.

Moreover, Chinese netizens have already proven to be a major player in the making of Chinese foreign policy. Indeed, on China's Japan policy, angry Chinese netizens appear to frequently take conciliatory policies off the table, forcing China's foreign policy elite to choose among a narrowing range of hard-line policies (see Gries 2005a).

To preview, I argue that while Chinese netizens feel coolly toward both Koreas, they think and feel about them in very different ways reflective of their own evolving understandings of what it means to be Chinese in the twenty-first century. Chinese netizens seem to be profoundly disillusioned with a North Korea that refuses to adopt the Chinese style of "reform and opening," which only reminds them of their own poor and authoritarian past. Given the Korean War's central role in Chinese nationalist narratives today, however, North Korea remains integral to Chinese nationalist understandings of China as a great power. As a result, despite disillusionment with both countries, Chinese netizens prefer a friendlier policy toward their former comrades in arms than toward the South. 
South Korea is seen very differently. It is viewed as an advanced industrial country to be emulated in many ways. South Korean television dramas (the "Korean wave") are popular in China, and watching them is associated with warmer feelings toward the ROK. But recent high-profile historical and cultural disputes appear to have led to widespread Chinese dismay and perhaps even anger toward a South Korea perceived as poaching on China's proud cultural heritage. As a result, Chinese netizens prefer a much tougher foreign policy toward a South Korea that they see as insufficiently deferential.

I begin with a brief qualitative historical analysis describing evolving Chinese views of the two Koreas. I then introduce quantitative evidence from a large national Internet survey of Chinese netizens conducted in the winter of 2010-2011. While combining qualitative and quantitative analysis is both burdensome and challenging, the qualitative analysis is essential to the interpretation of our quantitative data. Statistics do not speak for themselves. The historical background provides a vital framework within which to interpret the contemporary survey data.

While this article explores qualitative and quantitative evidence of what Chinese netizens feel and think about the two Koreas, it can provide little insight into how they come to hold such views or why. Like peoples everywhere, Chinese netizens are socialized into nationalist ideologies and narratives about the past that powerfully shape their views of foreign countries. The Chinese government, through its control of education and the media, is a major actor in this process. Of course, other social groups (e.g., parents, peers) and practices (e.g., popular culture) will impact an individual's international attitudes, as will individual differences in personality. The evidence here, however, is only sufficient to explore what Chinese netizens seem to feel and think about the Koreas, not the role of the government or other agents in generating those views.

\section{The Koreas: A Chinese Looking Glass}

In China and the American Dream, Richard Madsen argues that the Tiananmen Square Massacre of June 4, 1989, had a profound impact on American views of China. Furthermore, changing American attitudes had less to do with China itself than with American national identity. For Americans, the "moral drama" of Tiananmen actually involved an exercise in navel gazing, of "dreaming their social selves in face of the realities of the other" (Madsen 1995, xi). Specifically, Americans reveled in China's "reform and opening" in the 1980s, projecting their "liberal myth" onto China and Deng Xiaoping, who was even declared Time magazine's 1985 "Man 
of the Year" (Time 1985). China's embrace of the market was seen as affirming US capitalism and democracy. Tiananmen shattered that illusion, as the American image of Deng abruptly shifted from a capitalist "just like us" to a tyrant, the very antithesis of American liberalism.

In this essay, I explore the idea that something similar may be occurring in China today, with Chinese netizen feelings of disillusionment and dismay toward North and South Korea revealing much more about evolving Chinese understandings of themselves than they do about the two Koreas. Starting in the 1990s with the North Korean famine, and then accelerating in 2006 with North Korea's missile and nuclear weapons tests, elite Chinese views of North Korea have become more and more negative. Since then, elite disillusionment with North Korea appears to have spread to Chinese cyberspace. This Chinese reassessment of North Korea has been informed by both sense and sensibility. A rational argument that North Korea is undermining China's national interest in a secure and stable Northeast Asia has been accompanied by deep feelings of disillusionment: North Korea was refusing to emulate the Chinese model. Instead of affirming China's choice of reform, and thus becoming a mirror to and affirmation of a newly emerging Chinese national identity as a model of economic development, North Korea revealed itself to many Chinese to be governed by a Stalinist dictatorship, a selfidentity many Chinese had banished to a distant Maoist past.

Meanwhile, the last five to seven years have witnessed the end of the long Sino-South Korean honeymoon decade that began with the normalization of bilateral relations in 1992. Chinese netizens have been shocked by perceived South Korean challenges to their beneficent selfview. They do not understand why South Koreans contest Chinese historical and cultural hegemony over the region. While they appear to admire aspects of South Korean popular culture and modernity, South Korea painfully reminds them that not everyone shares their benign view of China's “peaceful rise" (和平崛起).

I argue here that Chinese views of the two Koreas are driven in large measure by evolving views of their own national identity. "Korea and the Chinese Dream" is a story that begins 700 years ago, moving from engagement in the imperial and Maoist periods, to disengagement and reengagement under Deng Xiaoping, and finally to disillusionment and dismay today.

\section{Engaging the Model Vassal: Tributary Chosun and "Little Brother" North Korea, Fourteenth Century to the 1970s}

Beginning in the fourteenth century, Chinese political elites engaged Korea with two clear objectives: to secure their northeastern flank and to 
legitimize their rule at home. The geopolitical significance of the Korean peninsula, situated at the heart of northeast Asia and between China and Japan, is self-evident from Korea's long history of being invaded by its neighbors. But from a Chinese perspective, Korea is a "dagger" pointed at China's neck.

But Ming and Qing Dynasty elites did not just engage Korea for strategic and military reasons. They also did so for domestic political purposes. Because the Chinese emperor claimed to rule "all under heaven" (天下), China's status as the "Middle Kingdom" (中国 ) required foreign confirmation. Ming Dynasty elites institutionalized Sino-Korean tributary relations in the fourteenth century not just to secure their northeastern flank, but also to legitimize Ming rule. As Gerrit Gong (1984, 131) rightly notes, "Fundamental to this establishment of China as the Middle Kingdom surrounded by tributary states was the acceptance by those surrounding states of China's [self-consciously superior] standard of 'civilization." "For six centuries, Chosun Korea was China's model vassal, adopting Confucianism and consistently reaffirming the superiority and centrality of Sinic civilization. Chung Jae Ho $(2007,13)$ writes, and I concur, that "from China's perspective, Korea had long been viewed as a model tributary, fervently emulating and internalizing much of China's ruling ideology and statecraft."

Interrupted by Japan's colonization of Korea during the first half of the twentieth century, China reestablished its "big brother-little brother" relationship with (now North) Korea under Mao Zedong in the 1950s-1970s. The relationship was cemented during the Korean War of the early 1950s. Mao's motives for entering the war were multiple and complex. While the strategic goal of securing New China's northeast (defending the Yalu River) played a role, so did a desire to utilize foreign conflict to mobilize and militarize domestic society for socialist transformation at home (see Chen 2001). But North Korea also played a vital role in affirming China's choice of communism and China's leading role in the communist movement. John Tkacik $(2006,143)$ is right that in choosing to enter the Korean War, Mao sought to demonstrate that China "was ready to lead the Socialist Revolution in the East." The role that North Korea played in affirming Maoist China's beneficent self-image is clear from the Chinese Communist Party's name for the Korean War: the "War to Resist America and Aid Korea" (抗美援朝战争). The ubiquity and longevity of the early 1950s photograph of an elderly Korean woman embracing a handsome young Chinese "volunteer" (see Figure 1) in Chinese histories of the war, and even online today, is similarly emblematic of the continuing role that North Korean gratitude continues to play in Chinese nationalist narratives about Chinese moral superiority today. 


\section{Figure 1 Chinese Photograph from the Korean War}

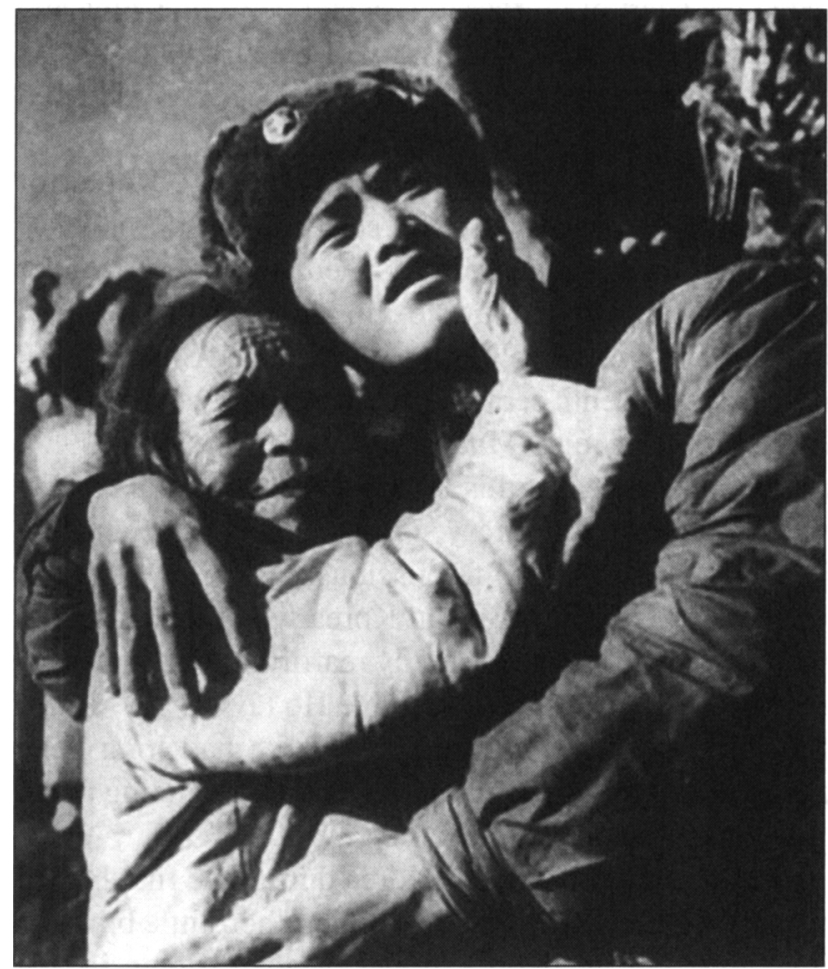

Source: tupian.hudong.com wiki.

Note: In this photograph, an elderly Korean woman embraces a "people's volunteer," affirming Chinese beneficence.

\section{Disengaging the North and Reengaging the South} Under "Reform and Opening" in the 1980s and 1990s In the 1950s and the 1960s, North Korea was the Korean peninsula's industrial powerhouse, and little brother's economic successes affirmed big brother China's choice of socialism. But by the late 1970s and 1980s, South Korea's economic development had surpassed North Korea's, and the Chinese gaze began to turn south. With the reforms of 1978, Chinese increasingly viewed South Korea as a model for emulation. In 1978, the Xinhua News Agency noted that South Korea's economic boom was worthy of Chinese attention, and in 1980, Hu Yaobang, then general secretary of the Chinese Communist Party (CCP), told journalists that China's policy of reform was based in part on the South Korean developmental experience (Chung 2007, 26-28). 
For its part, North Korea continued to stagnate in the late 1980s, as its economy fell further and further behind both South Korea's and China's. For many Chinese, North Korea was no longer a model vassal but was instead becoming an embarrassment.

These 1980s trends in Sino-Korean relations were dramatically accelerated as a consequence of the Tiananmen Square Massacre of 1989. China's elites, ostracized by the West after the massacre, actively sought to develop diplomatic relations around the world to reduce the PRC's international isolation. As then foreign minister Qian Qichen $(2005,149)$ notes in his memoir, China sought to "divide and demoralize the antiChina forces" by reestablishing relations with "weak links" in the Western coalition like Japan, as well as establishing new relationships with non-Western countries like South Korea. In my view, Sino-South Korean rapprochement in 1992, and the Sino-North Korean disengagement that accompanied it, cannot be understood apart from China's efforts to escape international isolation following Tiananmen. It was not simply the product of inexorable economic complementarities. ${ }^{1}$ The shift thus had a strategic dimension. But it also had a psychological dimension: by the 1990s, Chinese appeared to identify much more with the modern South than with the Stalinist North.

Following Sino-South Korean normalization in 1992, China's relations with North Korea deteriorated dramatically. China disengaged from North Korea through most of the 1990s. Samuel Kim (2004) has rightly noted that Sino-North Korean relations improved somewhat in 1999, as Chinese, alarmed by the war in Kosovo and the US bombing of the PRC Embassy in Belgrade, began to reassess their benign view of the international order. However, North Korea's increasing backwardness relative to both South Korea and China continued to redirect the Chinese gaze down the Korean peninsula.

\section{China's "Vietnam"? Growing Chinese Disillusionment with North Korea in the New Millennium}

Writing soon after North Korea's October 9, 2006, nuclear weapon test, Zhang Liangui $(2006,12)$, a leading Chinese North Korea expert at the CCP Central Committee Party School in Beijing, pondered: "Although North Korean nuclear weapons are not [currently] directed at China, no one can be sure how things may turn out in five or ten years. The lesson of Vietnam should not be forgotten. The political and economic center of China is on the eastern coastal areas, which are adjacent to North Korea. . . . North Korea [could] use its nuclear weapons to threaten or blackmail China." 
What is the "lesson of Vietnam" that Zhang is referring to? In 1979, during his first trip to the United States, Deng Xiaoping told then US president Jimmy Carter that China was planning to "teach Vietnam a lesson." Against China's wishes, Vietnam had invaded Cambodia and, worse yet, had allied itself closely with the Soviet Union, China's archenemy at the time. Given that China had provided the Vietnamese Communists with both material and moral support during their war with the United States just a few years earlier, Vietnam's actions were seen as a younger brother's betrayal of a beneficent older brother. It was therefore older brother's duty to put younger brother back in his place, and the People's Liberation Army (PLA) crossed the border from Yunnan into Vietnam on February 17, 1979, only to completely withdraw just four weeks later. The "lesson" perceived to have been taught the Vietnamese was purely symbolic-not instrumental.

That a prominent Chinese Communist Party analyst compared 2006 North Korea to 1979 Vietnam is quite striking. From Zhang's perspective, both are cases of former vassals or client states that betrayed China. The comparison, furthermore, begs the question: If China risked so much and was willing to pay such a high price to "teach Vietnam a lesson" in 1979, will Beijing seek to "teach North Korea a lesson" today as a result of North Korea's insolence? Also in 2006, Peking University's Zhu Feng $(2006,36)$ wrote that "a significant shift in Beijing's policy—entailing abandonment of its patron relationship with North Korea and coercion to roll back its nuclear capabilities-may be just around the corner." Although time has yet to bear out Zhu's forecast, his provocative suggestion reveals a growing elite Chinese disillusionment with North Korea.

For the first decade of the twenty-first century, Chinese analysts have held tightly to the belief that reform could save North Korea. A simple title search of East View's online China Academic Journals (CAJ) database reveals that from 1994 through 2001, there was on average less than one mainland Chinese journal article a year with the words North Korea and reform in its title. In the decade since 2001, however, there has been a heightened interest in the topic, with an average of over five articles a year. If only the North Korean government would adopt reform policies like China's, the general argument ran, the Korean situation could be contained and managed. However, North Korea's July and October 2006 missile and nuclear weapons tests appear to have begun a process of disenchantment in China, as Chinese elites in particular have begun to liberate themselves from what they increasingly see as their illusion of North Korean reform. As Scott Snyder $(2009,122)$ writes, "The Chinese leadership promoted their own reform experience as a model for eco- 
nomic development without ceding political control, but it seemed that North Korean counterparts were slow to get the message."

In the years prior to the 2006 tests, Chinese elites had sold themselves on the panacea of North Korean reform. From an instrumental perspective, reform was seen as the key means to a "smooth landing" for the North Korean regime, which would ensure stability on the Korean peninsula. Outside analysts largely agree that while the primary goal of US North Korea policy was preventing North Korea from going nuclear, China's primary goal was and remains regime stability in the north. Kim $(2004,162)$ writes, "China's greatest priority is peace and stability in the Korean peninsula, which is a key contributor to peace and stability within China ... not preventing Pyongyang from going nuclear." David Shambaugh (2003, 44-45) concurs, placing "regime survival" and "reform" at the top of his hierarchy of Chinese interests in the Korean peninsula: "For China ... the question is whether North Korea can embark on a sustained and comprehensive path of reform à la China." He notes that China has been actively marketing its successful reforms to Kim and the North Korean leadership, repeatedly showing off Zhongguancun, Shanghai, and Shenzhen to both Kim Jong Il himself and to the dozens of highlevel North Korean delegations that visit China annually.

But should North Korean reform be reduced to a mere means to China's goal of North Korean regime survival? I suggest that much more than instrumental reasoning is at stake. Citing interviews in Beijing, Shambaugh (2003, 45-46) reports that "China's Korea analysts draw explicit parallels to Maoist China and argue that North Korea's only viable option to avoid national suicide is to follow China's reformist example." Whether a North Korean policy of fundamental reform would in the end be stabilizing or destabilizing for the DPRK is a very debatable question. That Shambaugh's Chinese informants appear certain that it would be good for North Korea, therefore, may actually be more reflective of Chinese navel gazing than an objective assessment of the DPRK regime's best interests. A North Korean choice of reform today would affirm China's 1978 choice of "reform and opening" and its rejection of the Maoist past.

In short, it may be that in addition to considerations of China's instrumental interests, Chinese identity played a role in the intense anger that much of the Chinese elite experienced after the 2006 North Korean nuclear test. "In Beijing, ire turned to fury" after the test, writes Zhu Feng $(2006,40)$. "It was no less than a slap in China's face. . . . Without question, Beijing has become fully disillusioned about the nature of the Kim government." ${ }^{.3}$ China's elites saw North Korea as repudiating China's 
choice of reform and taking risks that could endanger China: "The missile tests . . . deeply shook the Chinese leadership's belief in the Kim Jong Il regime's ability to carry out reform and opening up in emulation of China's model. ... The current mentality of DPRK leaders is simplistic and arrogant. Pyongyang will not ... take decisive steps on the road of reform and opening" (Zhu 2006, 39).

Such elite disillusionment with North Korea appears to have spread via cyberspace among some Chinese netizens. A post entitled "North Korea Refuses Reform: The Kim Dynasty Warns China," which appeared on numerous Chinese websites in the spring of 2011, seems typical. It was written in response to a 2008 DPRK Workers News editorial, "Imperialists' Insidious 'Reform and Opening' Trap," which argued that "imperialists ... put huge pressure on other states who do not accept "reform' by labeling them 'isolationists." According to the Chinese author, "This [DPRK] editorial appears to criticize US-led Western countries, but is actually a warning to China: as long as Kim Jong Il is alive, you better not try anything." This alarms the Chinese author, who warns, "If China keeps supporting a corrupt regime, leaving the North Korean people to suffer, once they awaken, they will blame everything on China."

A selection of spring 2011 Chinese netizen comments to this posting on the popular Internet portal Netease is revealing. ${ }^{4}$ One netizen asserts that "North Korea is now quickly becoming a mad dog." Another, likely invoking Vietnam, laments that "China always raises heartless regimes that repay kindness with enmity." Another thoughtfully reveals the continuing centrality of the Korean War to Chinese identity: "Such a sadness for us! So many of our soldiers gave their lives [for them]." As Zhu Feng $(2006,35,44)$ has acknowledged, "A residual sympathy for North Korea remains in China." This sympathy appears tied to the continuing centrality of the Korean War to narratives of Chinese nationalism today.

\section{Cultural Kleptos! Growing Chinese Dismay at South Korean "Cultural Robberies"}

In July 2004, a Chinese United Nations Educational, Scientific, and Cultural Organization (UNESCO) claim that the ancient kingdom of Goguryo (37 B.C.E.-668 C.E.) was China's vassal state ignited a firestorm of protest in South Korea. Chinese were stunned by the extent of South Korean anger, played out in newspaper editorials, the Internet, and even street demonstrations in front of the Chinese Embassy in Seoul. In Chinese eyes, Korea has long been part of Sinic civilization and a Sino-centric East Asian regional order (see Gries 2005b). Confidence in China's ability to 
reconstruct a hierarchical East Asian regional order in the twenty-first century is tied in part to proud stories about a past tributary system in which vassals like Korea paid humble tribute to the Chinese center. Because Chinese, like all peoples, view the groups to which they belong as inherently good, they likely simply did not imagine that Koreans would object to being part of a past and future Pax Sinica. Furthermore, Korean rejection of “China's Gaogouli" (中国高句丽), the possessive Chinese construction used to describe the Kingdom, was likely met by the anger of those who feel their cherished in-group identities are being challenged.

The controversy did not die. During an awards ceremony at the 2007 Asian Winter Games in Changchun, China, a group of five female South Korean athletes held up a sign declaring, "Mount Baekdu is our territory." What Chinese call Changbaishan (长白山) had been partitioned between China and North Korea in 1962. Many South Koreans today view Mount Baekdu as sacred Korean territory that China illegitimately seized. Regardless, this 2007 incident was widely publicized in Chinese cyberspace and contributed to a growing Chinese view of Koreans as fierce nationalists with irredentist ambitions. For instance, one Chinese netizen posted a satirical map of the "South Korean View of the World" on a Chinese humor website. The entire globe is depicted as "ours, ours, ours" (see Figure 2).

Figure 2 Chinese Netizens Deride South Korean Nationalism

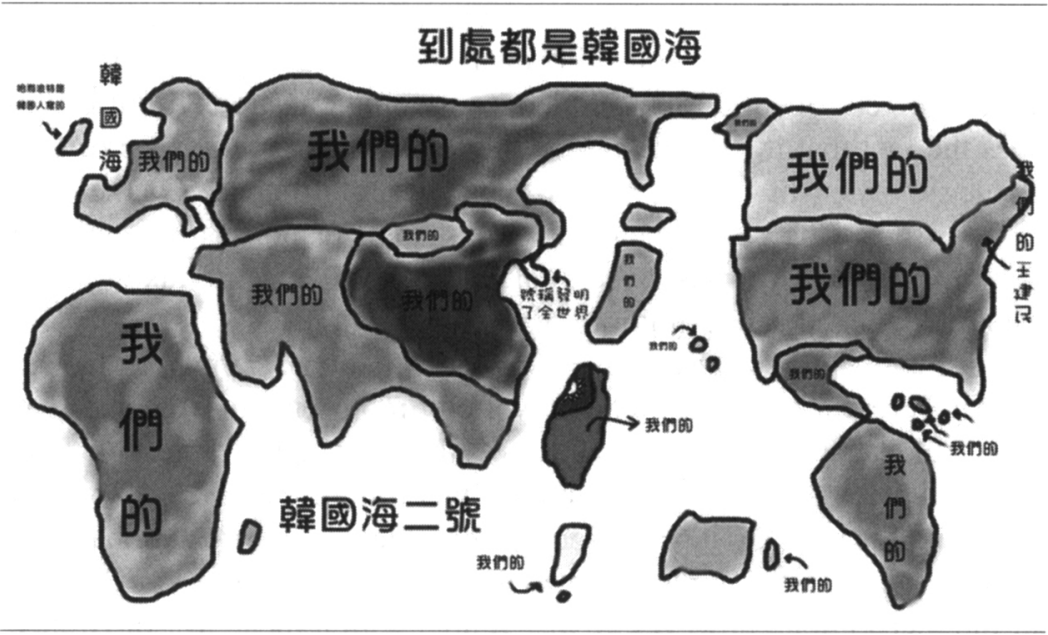

Source: "South Koreans" entry in the Chinese edition of the Uncyclopedia, a Wikipedia farce (http://cn.uncyclopedia.wikia.com; accessed June 1, 2011).

Note: In this drawing, Chinese netizens mock the South Korean "view of the world" ("ours, ours, ours ..."). 
Cultural disputes have emerged as well. In 2005, South Korea applied to UNESCO and was granted recognition for its "Dano" dragon boat festival, celebrated on the fifth day of the fifth lunar month. Chinese viewed this as "cultural robbery," as China's "Duanwu" dragon boat festival (端午节) is celebrated on the very same day. So in 2009, China applied to UNESCO for recognition of its own Duanwu Festival. Chinese netizens have also maintained that South Koreans claim both Chinese characters and Confucius as Korean. Indeed, a sarcastic rumor even went around Chinese cyberspace that because popular Chinese blogger Han Han's (韩寒) surname is the same as the character for Korea (韩国), Koreans were claiming that he is Korean as well. ${ }^{5}$

In short, qualitative evidence suggests that Chinese netizens appear increasingly dismayed about a South Korea seen as poaching on China's historical and cultural heritage. This dismay can be expressed as humorous jibes about South Koreans as cultural kleptos, or in a deeper anger at a South Korea seen as challenging China's beneficent self-view.

\section{National Internet Survey Evidence}

Survey data can further our understanding of Chinese views of the two Koreas. In the winter of 2010-2011, 2,506 Chinese netizens began a lengthy online Internet survey; 1,413 completed it. While this completion rate is somewhat low, it was a very long survey with numerous lengthy rating scales. Furthermore, the survey was taken voluntarily, with no remuneration, after clicking on a link on a Chinese website. This allows us to be more confident that respondents answered questions truthfully, as does the fact that it was an Internet survey. Unlike face-to-face or telephone surveys, which are subject to social desirability biases in the interview process whereby participants adjust their responses to what they think the interviewer wishes to hear, Internet surveys are taken in private, reducing social desirability biases.

Using the Internet also allowed for a truly national sample, with every Chinese province and provincial-level city represented, Tibet and Xinjiang included. Guangdong province was the most highly represented, but at just 14 percent of the sample, and no other province exceeded 6 percent of the sample total. So it was a very geographically diverse national sample, not concentrated in just a few major cities. As might be expected for an Internet sample, however, it was young, with a mean age of twentythree $(S D=6)$. A majority (61 percent) were college educated, followed by high school (23 percent) and middle school (12 percent) graduates. A majority described their incomes as "middle/average," followed by "lower 
middle" (27 percent), and "upper middle" (13 percent); 60 percent were male, 51 percent claimed a rural (as opposed to urban) upbringing, and 94 percent identified as Han. In short, although it was a convenience sample, it was a remarkably diverse sample of young Chinese netizens. To our knowledge, it is the only such survey to include extensive questions about the international attitudes of China's netizens. It should not, however, be taken to represent the full Chinese population.

To explore Chinese netizen perceptions of the relative hard and soft power of foreign countries, two lengthy rating scales tapped how "economically and militarily powerful” (经济与军事实力) and how “culturally influential" (文化影响力) twenty foreign countries were. The answer choices were on seven-point Likert-style rating scales from "extremely weak" to "extremely strong" and "not influential at all" to "extremely influential." For each scale, the sequence in which the twenty countries were presented was randomized.

Figure 3 displays the mean scores for each of the twenty countries, with perceived material power on the horizontal axis, and perceived cultural influence on the vertical axis. Assessments of the hard and soft power of the twenty countries were highly congruent $\left(R^{2}=.87\right)$. Vietnam was seen as the weakest country in terms of both hard and soft power. But there was more ambivalence about who was the most powerful, with Chinese netizens viewing the United States as possessing by far the most material power but China having the most cultural influence.

In terms of the two Koreas, our Chinese netizens viewed South Korea as possessing more hard and soft power than North Korea. On hard power, a t-test revealed that Chinese netizens $(N=1,315)$ viewed South Korea $(M=3.69)$ as much more economically and militarily powerful than North Korea $(M=2.86, t=-21.87, p<.001)$.

The survey also included separate rating scales measuring foreign policy preferences and country feelings. Foreign policy preferences were measured with a seven-point rating scale asking whether respondents desired a “friendlier” (更友好) or “tougher” (更强硬) foreign policy toward nineteen countries (excluding China). Feelings toward all twenty countries (including China) were measured with an eleven-point "feeling thermometer" (温度计) from $0^{\circ}$ to $100^{\circ}$ by tens.

Perceived economic and military power proved to be a poor predictor of netizen foreign policy preferences, however, with no relationship at all between their mean scores $\left(R^{2}=.008\right)$. Instead, feelings toward foreign countries proved to be a better predictor of foreign policy preferences. In a simultaneous multiple regression with assessments of North 


\section{Figure 3 Chinese Netizens' View of Hard and Soft Power Around the World}

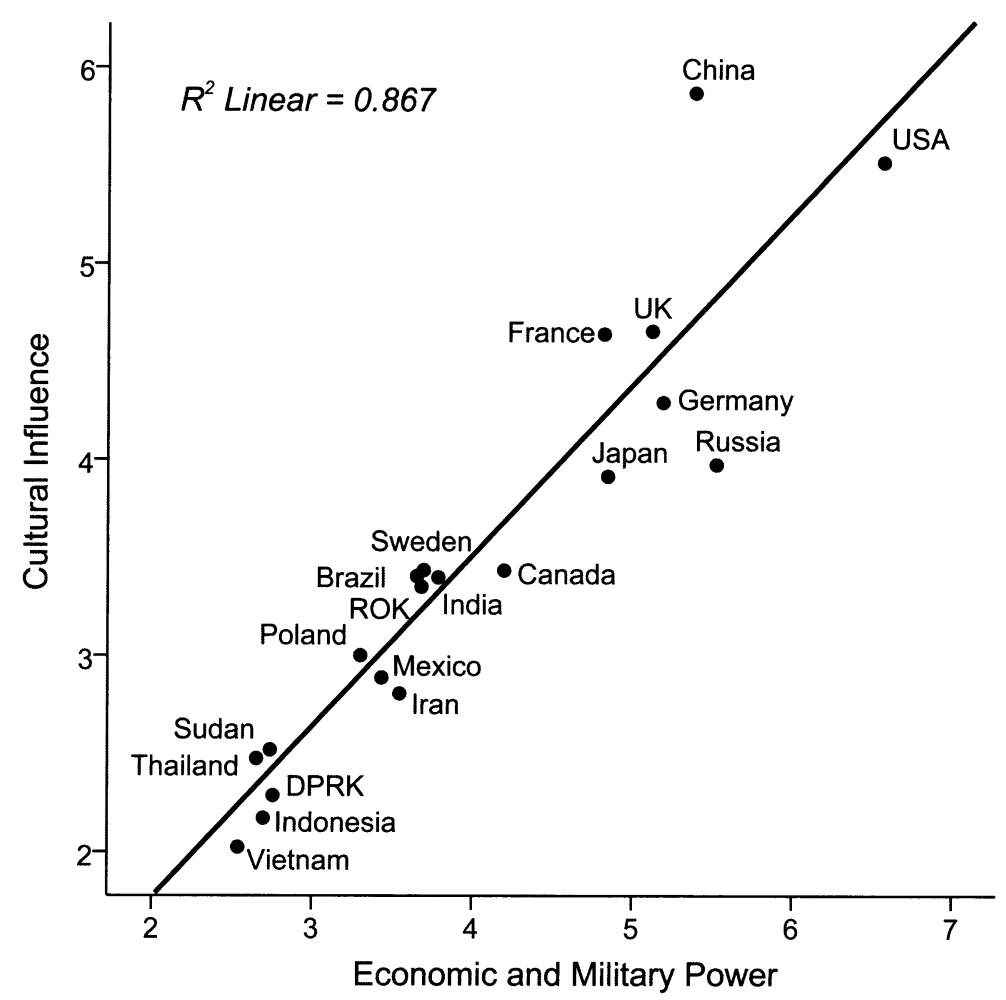

Source: University of Oklahoma Political Psychology of US-China Relations research lab.

Note: The diagram shows that Chinese netizens view South Korea as more economically and militarily powerful and more culturally influential than North Korea.

Korean economic and military power and feelings toward North Korea predicting North Korea policy preferences, only feelings were significant $(\beta=$ $-.30, p<.001)$, accounting for 10 percent of the variance in policy preferences. A similar regression with the same variables for South Korea did find a statistically significant impact of assessments of South Korean power $(\beta$ $=-.10, p<.001)$ on ROK policy preferences $\left(R^{2}=.19\right)$, but it was much smaller than the effect of feelings toward South Korea $(\beta=-.39, p<.001)$.

Figure 4 displays mean country scores for the feeling thermometer on the horizontal axis, and foreign policy preferences on the vertical axis. There was a modest relationship between the two $\left(R^{2}=.23\right)$, with greater 
warmth toward a country associated with desires for friendlier policies toward it. The figure shows that although Chinese netizens felt rather coolly toward both Koreas, they felt slightly warmer toward the South but preferred a much friendlier policy toward the North. Statistical analysis confirms this eyeball assessment. A t-test revealed that Chinese netizens $(N=2,506)$ felt slightly warmer toward South Korea $\left(M=41^{\circ}\right)$ than toward North Korea $\left(M=39^{\circ} ; t=-3.7, p<.001\right)$. But a subsequent t-test revealed that Chinese netizens $(N=1,410)$ preferred a much friendlier policy toward North Korea $(M=3.08)$ than toward South Korea $(M=$ 4.15), $t=-21.52, p<.001$.

Figure 4 Chinese Netizens' Feelings and Foreign Policy Preferences Toward Foreign Countries

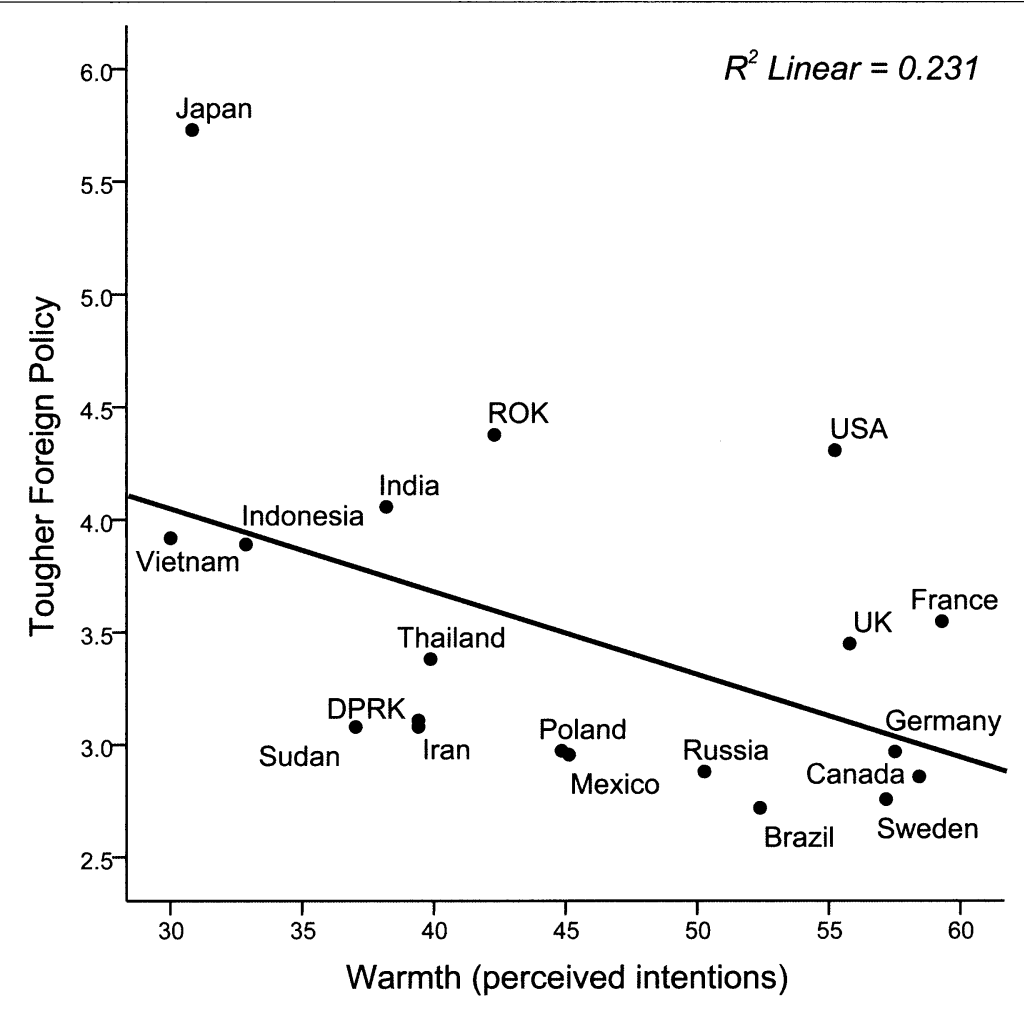

Source: University of Oklahoma Political Psychology of US-China Relations research lab.

Note: The diagram shows that Chinese netizens feel slightly warmer toward South Korea than toward North Korea, but prefer a much tougher foreign policy toward South Korea. 
We have thus uncovered our first empirical puzzle: our Chinese netizens felt slightly warmer toward the South than the North and yet desired a much tougher policy toward the South than the North. Why?

\section{Structures of Chinese Netizen Feelings Toward the Two Koreas}

Although our netizens felt similarly coolly toward both North and South Korea, there are nonetheless important differences in their structures of feeling toward them. To better understand just how our Chinese netizens perceived the two Koreas, exploratory factor analysis (EFA) was used to see whether feelings toward the nineteen foreign countries included in our survey (Brazil, UK, Canada, DPRK, France, Germany, India, Indonesia, Iran, Japan, Mexico, Poland, ROK, Russia, Sudan, Sweden, Thailand, USA, and Vietnam) would cluster into a single or multiple factors. EFA is a statistical technique that is used to discover the latent dimensions or unobserved variables called "factors" that undergird a larger number of observed variables such as individual survey items. Principal axis factoring (PAF) was conducted on the full dataset, followed by Promax rotation with Kaiser normalization to aid in the interpretation of the factors. ${ }^{6}$ The third, fourth, and fifth columns in Table 1 present the results, displaying all loadings greater than .30. PAF produced three factors with Eigenvalues greater than one, the conventional minimum $(7.35,2.26$, and 1.52 respectively). Eigenvalues represent the amount of variance in the original set of variables accounted for by a factor.

Table 1 reveals that feelings toward North and South Korea clustered together with very different sets of countries. Countries were considered to cluster together into a factor if they loaded onto that factor, and that factor only, at greater than .35 , a conventional factor minimum. The first factor included (in order of the strength of their factor loadings) Vietnam, Indonesia, India, North Korea, Thailand, and Iran and has been labeled "Asian developing countries." The second factor included Sweden, Canada, Germany, Poland, Mexico, and Brazil and is labeled "EuroAmerican" countries. The third factor included the United States, France, Japan, and South Korea, and is labeled "advanced industrial" countries.

It is thus notable that region/race, developmental status, and possibly perceived rivalry all contributed to structuring the ways that our Chinese netizens felt about foreign countries. China's weaker Asian neighbors structured together into the first factor. These developing countries were all looked down upon coolly, with a mean temperature of just $36^{\circ}$. Overall, our Chinese netizens felt much warmer $\left(52^{\circ}\right)$ toward the five more advanced 
Table 1 Structures of Chinese Netizen Feelings Toward Foreign Countries

\begin{tabular}{lcccc}
\hline Country & $\begin{array}{c}\text { Mean } \\
\text { Temperature } \\
\text { (warmth) }\end{array}$ & $\begin{array}{c}\text { Factor 1: Asian } \\
\text { Developing } \\
\text { Countries }\end{array}$ & $\begin{array}{c}\text { Factor 2: Euro- } \\
\text { American } \\
\text { Countries }\end{array}$ & $\begin{array}{c}\text { Factor 3: } \\
\text { Advanced } \\
\text { Industrial } \\
\text { Countries }\end{array}$ \\
\hline Vietnam & $30^{\circ}$ & $0.822^{\mathrm{a}}$ & & \\
Indonesia & $32^{\circ}$ & $0.684^{\mathrm{a}}$ & & \\
North Korea & $39^{\circ}$ & $0.655^{\mathrm{a}}$ & & \\
Thailand & $39^{\circ}$ & $0.594^{\mathrm{a}}$ & & \\
India & $39^{\circ}$ & $0.580^{\mathrm{a}}$ & & \\
Iran & $39^{\circ}$ & $0.567^{\mathrm{a}}$ & 0.317 & \\
Sudan & $36^{\circ}$ & 0.520 & 0.419 & \\
Mexico & $44^{\circ}$ & 0.361 & 0.537 & \\
Russia & $50^{\circ}$ & 0.305 & & \\
Sweden & $55^{\circ}$ & & $0.815^{\mathrm{a}}$ & \\
Canada & $57^{\circ}$ & & $0.714^{\mathrm{a}}$ & \\
Germany & $56^{\circ}$ & & $0.689^{\mathrm{a}}$ & \\
Poland & $44^{\circ}$ & & $0.681^{\mathrm{a}}$ & \\
Brazil & $50^{\circ}$ & & $0.526^{\mathrm{a}}$ & \\
Great Britain & $55^{\circ}$ & & 0.382 & 0.589 \\
United States & $55^{\circ}$ & & 0.318 & $0.655^{\mathrm{a}}$ \\
France & $59^{\circ}$ & & & $0.599^{\mathrm{a}}$ \\
Japan & $31^{\circ}$ & & 2.26 & $0.526^{\mathrm{a}}$ \\
South Korea & $41^{\circ}$ & 0.328 & 1.52 \\
Eigenvalues & & 7.35 & & \\
\hline
\end{tabular}

Source: University of Oklahoma Political Psychology of US-China Relations research lab. Notes: Pattern matrix loadings for principal axis factor analysis with Promax rotation. Factor coefficients are shown only if greater than 0.30 .

a. Scores load cleanly at greater than .35 on just one factor.

"Euro-American" countries that loaded onto our second factor. Note that Sudan, Mexico, and Russia did not load cleanly onto either of the first two factors, struck between the Asian developing and Euro-American more developed worlds. Finally, Japan and South Korea, China's northeast Asian rivals, clustered together with the United States and France, China's global rivals. It is notable that Great Britain cross-loaded onto the more positive Euro-American factor too highly to cleanly load onto the third factor, suggesting that the UK is seen as less of a psychological rival than France, which China has had significant conflicts with recently. ${ }^{7}$

This factor analysis of feelings toward foreign countries clearly demonstrates that while Chinese netizens feel comparably coolly toward both Koreas, they think about them in very different ways: North Korea 
is seen as one of many poor Asian neighbors, likely to be pitied or looked down upon, while South Korea is lumped together with China's advanced industrial rivals, the United States, France, and Japan.

\section{Correlates of Chinese Netizen Feelings and Foreign Policy Preferences}

If North Korea is seen as poor and pitiable, that might explain why our Chinese netizens display a (compassionate?) desire for a friendlier North Korea policy. And if South Korea is seen as an advanced industrial rival lumped together with Japan and the United States, that might account for their desires for a relatively tougher ROK policy (see Figure 3). But why then do these Chinese netizens not feel even more coolly toward South Korea?

Our Internet survey included other questions that suggest a cultural effect whereby an affinity for popular South Korean television dramas and celebrities warms up what might otherwise be even cooler Chinese netizen feelings toward South Korea. For instance, we included one question asking respondents how many hours they had spent over the previous week watching Korean television dramas. While well over 50 percent reported watching none at all, there was still sufficient variation to reveal an exposure effect on feelings toward South Korea (see Figure 5). ${ }^{8}$ Two one-way analysis of variance (ANOVA) revealed that greater exposure to Korean TV dramas was associated with substantially greater warmth toward South Korea $\left(F[6,530]=8.16, p<.001, \eta_{p}^{2}=.09\right)$ but not toward North Korea $\left(F[6,530]=.751, p=.61, \eta_{p}^{2}=.01\right)$. In nonstatistical terms, the mean feelings toward South Korea for those who reported not watching Korean dramas at all over the previous week was $33^{\circ}$, well below the sample average of $39^{\circ}$, while those who reported watching two or more hours of Korean dramas over the previous week reported substantially greater warmth $\left(48^{\circ}\right)$ toward South Korea.

We also asked our Chinese netizens to tell us how much they liked a list of Asian and US celebrities. One was female Korean celebrity Chae Yeon (채연 or 蔡妍 Cai Yan in Chinese). Judgments of Chae on a sevenpoint "strongly dislike" to "strongly like" scale correlated positively with warmth toward South Korea $(r=.21)$, with a very small positive spillover effect on warmth toward North Korea $(r=.07)$. Similarly, liking male Chinese singer Han Geng (韩庚), who was trained in a South Korean boy band, also correlated positively with warmth toward South Korea $(r=.21)$, with a very small positive spillover effect on warmth toward North Korea $(r=.06)$. Furthermore, we found that female Chinese netizens $\left(44^{\circ}\right)$ felt warmer toward South Korea than $\operatorname{did}$ men $\left(37^{\circ}\right),(F[1037]=21.17, p<$ 
Figure 5 Effect of Exposure to South Korean Television Dramas on Chinese Netizens' Feelings Toward the Two Koreas

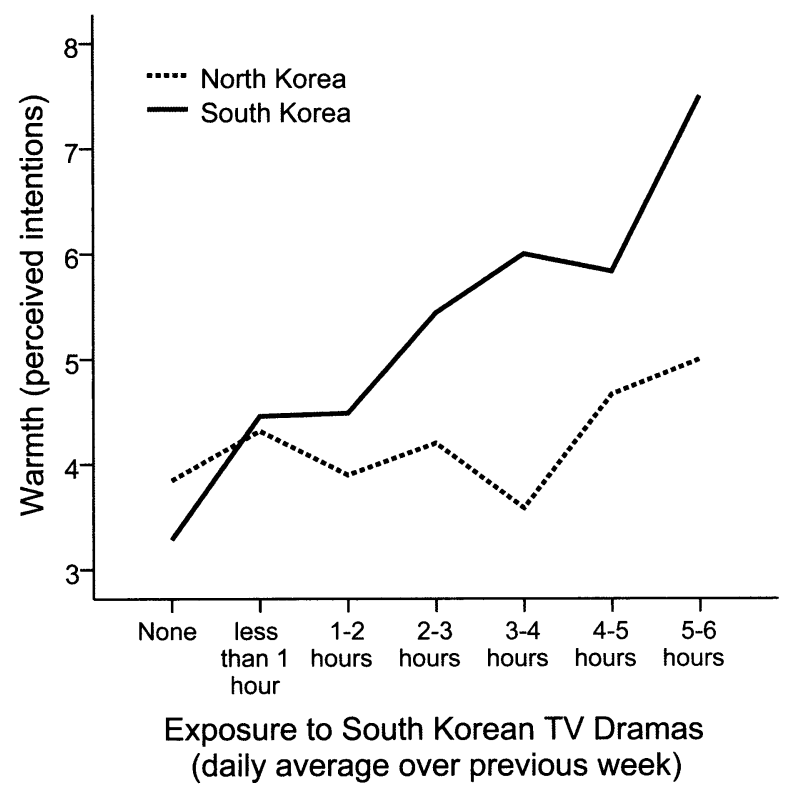

Source: University of Oklahoma Political Psychology of US-China Relations research lab.

Note: The graph shows that exposure to South Korean television dramas increases Chinese netizens' warmth toward South Korea but not North Korea.

$\left..001, \eta_{p}^{2}=.02\right)$. But this gender effect disappeared when controlling for watching Korean television dramas $\left(F[1,301]=2.27, p=.13, \eta_{p}^{2}=.007\right)$. There was no gender difference on feelings toward North Korea.

In short, our survey provides convergent evidence that the "Korean wave" (韓流) appears to mitigate against even cooler Chinese netizen feelings toward South Korea.

Like indirect contact with South Korea via television and the Internet, direct contact with Asians appears to improve Chinese netizens' feelings toward South but not North Korea. Our national Internet survey included two items on this foreign contact: "How often do have contact with people from other Asian countries" and "How many friends do you or your good friends have who are from other Asian countries?" Answers to these two items were averaged to form an "Asian friends/contact" scale $(\alpha=.71)$ that captures both the quantity and quality of contact with non-Chinese Asians. The scale correlated positively with warmth toward South Korea $(r=.10, p<.001)$ but marginally negatively with warmth 
toward North Korea $(r=-.06, p=.04)$. In other words, the more friends or contact a Chinese netizen claimed to have with other Asians, the more coolly they felt toward North Korea. Given the large numbers of South Koreans in China, the odds are that the "Asian" contacts and friends that Chinese netizens reported disproportionately involved South Koreans. ${ }^{9}$

Beliefs about China's past tributary relationship with Korea also impacted Chinese netizen feelings toward South but not North Korea. As Kirk Larsen $(2008,32)$ notes, "Choson Korea was as close to a model tributary state as China ever found." Our Internet survey included a single item stating that "the tributary system was good for ancient China's vassal states." Agreement with this statement $(n=1,318)$ was associated with less warmth toward South Korea $(r=-.09, p=.001)$ but had no impact on feelings toward North Korea $(r=.02, p=.44)$.

The Internet survey also included two individual differences or dispositional variables that might be expected to impact Chinese netizen views of the two Koreas. Han ethnocentrism, measured as the difference between warmth toward the Han and the average of the warmth toward two minorities-Tibetans and Uighurs-was associated $(n=1,640)$ with greater coolness toward both North $(r=-.16, p<.001)$ and South $(r=$ $-.08, p=.002$ ) Korea. That said, Han ethnocentrism was associated with greater coolness toward sixteen of the other seventeen countries in the survey as well. (Han ethnocentrism was not significantly associated with feelings toward the United States, $r=-.04, p=.11, n=1,640$, perhaps because the United States is the global superpower so other variables are more important in predicting attitudes toward it.)

Chinese nationalism, defined here as a belief in China's superiority over other nations, was measured with three items: "China is the best country in the world"; "The Chinese model is superior to that of other countries"; and "Given China's lengthy history and glorious civilization, China should lead East Asia." The resulting Chinese nationalism scale $(\alpha=.71)$ was associated $(n=923)$ with desires for a friendlier North Korea policy $(r=-.12, p<.001)$ but had no impact on foreign policy preferences toward South Korea or on feelings $(n=1,115)$ toward either North or South Korea.

\section{Separate Pathways to Feelings and Policy Preferences Toward the Two Koreas}

Figure 6 displays all of these variables together in a single path model. Path analysis has a number of advantages over multiple regression, such as including more than one dependent variable, modeling mediated relationships among variables, and evaluating the global fit of a model con- 
taining those mediated relationships. However, the use of cross-sectional data means that as with regressions our path model cannot provide conclusive evidence of causality.

Our path model reveals, first and foremost, that the determinants of Chinese netizen feelings and policy preferences toward the two Koreas are largely separate. This confirms what our exploratory factor analysis had already suggested. The only variable that had an impact on feelings or policy preferences toward both Koreas was Han ethnocentrism, a deep-rooted preference for the Han and disdain for other national groups (with the exception of the United States). It is noteworthy that this dis-

\section{Figure 6 Dispositional and Situational Determinants of Chinese Netizen Feelings and Policy Preferences Toward the Two Koreas}

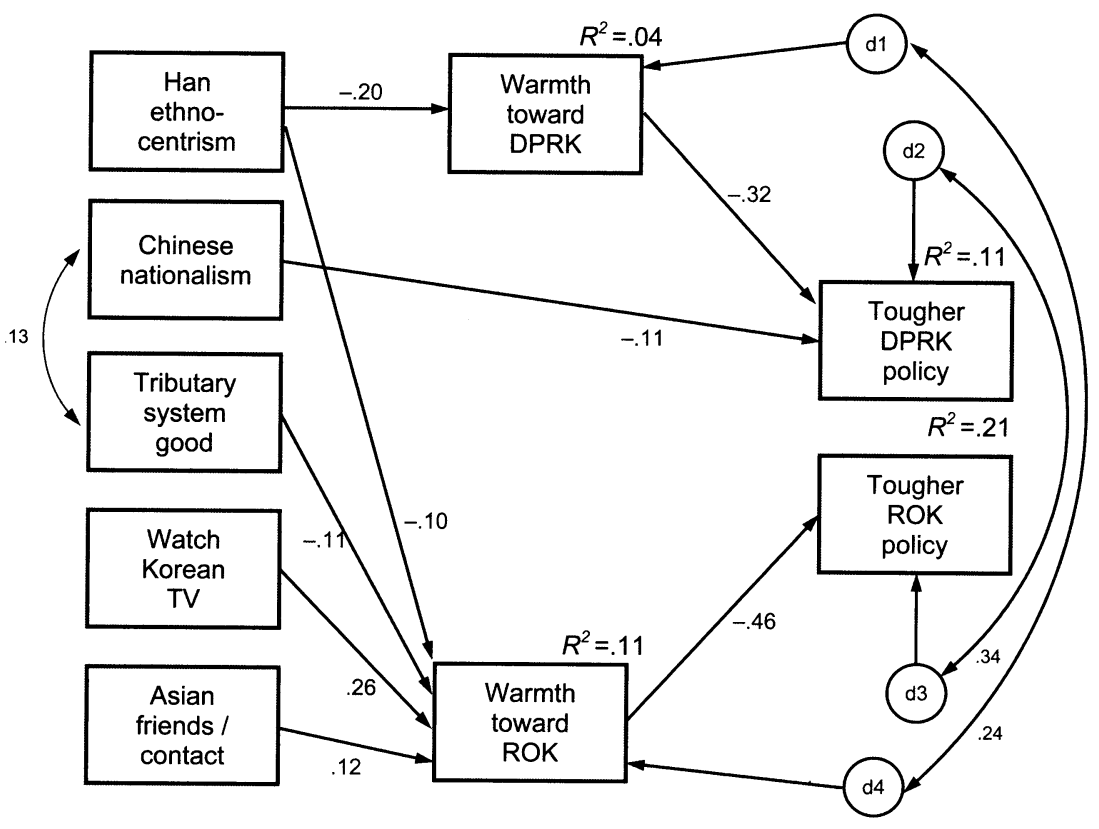

Source: University of Oklahoma Political Psychology of US-China Relations research lab.

Note: The path model reveals that the sources of Chinese netizens' feelings and policy preferences toward the two Koreas are largely separate. $\mathrm{N}=304$; all coefficients significant at $\mathrm{p}<$ .05. Fitness statistics: $x^{2} / \mathrm{df}=.54$; TLI $=1.092 ; \mathrm{CFI}=1.000 ; \mathrm{NFI}=.937$; RMSEA $<.001$; where $x^{2}=$ chi-square; $\mathrm{df}=$ degrees of freedom; $\mathrm{CFI}=$ comparative fit index; $\mathrm{NFI}=$ normed fit index; TLI = Tucker-Lewis Index; RMSEA = root mean square error of approximation. See Kline (2005) for fitness statistics conventions. 
dain had a greater impact on feelings toward North Korea than toward South Korea, perhaps suggesting that as a poor Asian neighbor, the North is looked down upon more than the South, whose advanced industrial nature may mitigate against the effects of ethnocentric bias. Overall, however, what is most noteworthy is that the determinants of foreign policy preferences toward North and South Korea were largely separate.

The second exogenous variable is nationalism, which is only associated with a desire for a friendlier foreign policy toward the North $(\beta=$ $-.11)$. This is likely best explained by the central role that the Korean War continues to play in the construction of a Chinese nationalism that depicts China as superior to rivals such as the United States. Given all the Korean War movies that were rerun in 2010 China to commemorate the Korean War's sixtieth anniversary, it should not be surprising that more nationalist Chinese netizens were more likely to advocate friendlier policies toward a North Korea that China is seen as helping to defeat the United States.

Greater endorsement of the statement that the traditional Chinese tributary system was good for China's Asian neighbors was associated with greater coolness $(\beta=-.11)$ toward a South Korea seen as insufficiently deferential toward China but had no impact on feelings toward North Korea. This is likely due to the fact that the South, as a democracy, has been more open and vocal in voicing its position on history disputes with China. Pyongyang has actually sided with Seoul against Beijing on these historical controversies, but Chinese netizens are not likely aware of this. They appear to be very aware, however, of South Korean claims to "Goguryo," generating greater coolness toward South Korea.

Finally, two situational variables-exposure to South Korean television dramas $(\beta=.26)$ and Asian friends and contacts $(\beta=.12)$-were both positively associated with greater warmth toward South Korea, counterbalancing the negative effects of historical beliefs and Han ethnocentrism. Given North Korea's isolation from China, it is not surprising that these situational variables had no impact on feelings or policy preferences toward North Korea.

\section{Conclusion: Korea and the Chinese Dream}

Much in Sino-North Korean relations today is well described in structural and material terms. Michael Chambers (2005) has noted that the relationship has taken on features of a typical alliance dilemma: the stronger alliance partner (China) fears entrapment, while the weaker partner (North Korea) fears abandonment. Hence, Chinese like the Chinese 
Academy of Social Science's Shen Jiru (2003) have raised the idea of revoking the military alliance component of the 1962 Treaty of Friendship, Cooperation, and Mutual Assistance between the PRC and the DPRK. And the North Koreans, fearing Chinese abandonment with the end of the Cold War, the Tiananmen Square Massacre, and Beijing's embrace of South Korea, have turned from external to internal balancing through the development of a nuclear deterrent.

China's interest in North Korean reforms is also well described in material terms. As Avery Goldstein $(2006,141)$ has recently noted, "Reforms in North Korea would advance China's reputational as well as its intrinsic [read: material] interests." China has staked its reputation as a "responsible great power" on hosting the Six-Party Talks. By serving as a buffer between China and both South Korean and US troops, North Korea serves China's vital security interests as well. As Fudan University's Shen Dingli $(2006,20)$ notes, "North Korea acts as a guard post for China, keeping at bay the tens of thousands of US troops stationed in South Korea. This allows China to reduce its military deployment in northeast China and focus more directly on the issue of Taiwanese independence." And North Korean reform is also in China's socioeconomic interest, as it would lessen North Korea's need for Chinese aid and stem the tide of economic and political refugees pouring into China. As a Chinese official said, "We can either send food to North Korea or they will send refugees to us - either way, we feed them. It is more convenient to feed them in North Korea" (cited in Kim 2004, 116). In short, many Chinese seem to see North Korean reform as stabilizing the Kim Jong Il regime and thus serving China's material interest.

China's engagement with South Korea over the last two decades is also well described in instrumental terms. To combat its international ostracism following the Tiananmen Square Massacre of 1989, China strategically sought to normalize relations with South Korea. Trade and investment relations with South Korea also served China's goal of economic development and modernization.

Rather than contest such materialist arguments, I supplement them in this article with a focus on the identity politics that also drives China's policies toward the two Koreas. Qualitative and quantitative evidence has provided convergent evidence that Chinese netizens look coolly upon the two Koreas, but for very different reasons. North Korean reform may serve China's strategic interests, but it also serves as a mirror to an evolving Chinese national identity. Chinese today are very different from Chinese under Mao, and that is reflected in their evolving views of North Korea. Where elite Chinese sought to engage (North) Korea in the impe- 
rial and Maoist periods, and then disengaged from North Korea under "reform and opening" in the 1980s and 1990s, they appear to be entering a period of disillusionment today. North Korea's 2006 missile and nuclear weapons tests revealed North Korea to be a mirror to China's own Maoist past rather than an affirmation of China's choice of reform in the twenty-first century. While Chinese netizens appear to look coolly upon a backward North Korea, however, the shared legacy of the "War to Resist America and Aid Korea," and its continued centrality to Chinese nationalist narratives, also appears to engender a sympathy or loyalty that leads to desires for a friendlier North Korea policy.

Chinese netizens also appear to be of two minds about South Korea. On the one hand, they find the "Korean wave" and South Korean modernity alluring, generating favorable feelings and warmth. On the other hand, historical and cultural disputes with South Korea have generated feelings of dismay. South Koreans are seen as poaching on China's cultural heritage, humiliating China. They also appear to be seen as challenging cherished dreams of a future Pax Sinica.

Chinese netizen feelings toward the two Koreas thus appear to tell us much more about evolving Chinese views of their own national identity and role in the twenty-first-century world order than they do about the two Koreas themselves. This should not be surprising: few people around the world know much about foreign countries, so most simply project their own fears and fantasies onto foreign Others. Like "China and the American Dream," "Korea and the Chinese Dream" is primarily an exercise in navel gazing.

Peter Hays Gries is the Harold J. and Ruth Newman Chair in US-China Issues and director of the Institute for US-China Issues at the University of Oklahoma. He is the author of China's New Nationalism (2004) and coeditor of Chinese Politics (2010) and State and Society in 21 st-Century China (2004). He has also written numerous academic journal articles and book chapters. His work focuses on the political psychology of US-China relations.

\section{Notes}

An earlier version of this article was presented at the Asan Institute for Policy Studies in Seoul, South Korea. The author would like to thank Hahm Chaibong and Asan for their hospitality and for their permission to publish this paper here. He would also like to thank Gilbert Rozman, Stephan Haggard, and two anonymous JEAS reviewers for their thoughtful comments.

1. I thus differ on this specific point from Chung Jae Ho, who has written one of the few detailed studies of the Sino-South Korean normalization in the 
early 1990s. Chung downplays the role of the Tiananmen Massacre (which he refers to as an "incident") in spurring Chinese efforts toward normalization (see Chung 2007, 44-46).

2. Less known is the fact that not only did the Carter administration give China the "green light" to invade Vietnam, but National Security Advisor Zbigniew Brzezinski met with the Chinese ambassador to Washington nightly during the war to share US intelligence on Soviet troop movements with the Chinese. The United States in effect secured China's rear flank during its invasion of Vietnam (see Mann 1998, 98-100).

3. Emphasis added. As evidence, Zhu $(2006,41)$ further notes that "China called Pyongyang's action flagrant (hanran 悍然), a word that is normally employed only for criticizing actions by an adversary."

4. See http://bbs.news.163.com/bbs/mil/107079190.html (accessed October 27, 2011).

5. See http://zhidao.baidu.com/question/146050019.html?fr=qrl\&cid=204\& index $=3$ (accessed June 7, 2011).

6. On the choice of PAF for EFA, see Russell 2002.

7. After a series of incidents involving the Dali Lama and the Olympics around 2008, many Chinese now view President Nicolas Sarkozy and France as hostile to China.

8. An eighth and last category, "six or more hours," was excluded from analysis because there were too few respondent in that category $(n=21)$, and it appeared that several were not following instructions.

9. There are large numbers of people from Taiwan and Hong Kong in China as well, but Chinese netizens would likely view them as compatriots, not as people from "other Asian countries."

\section{References}

Chambers, Michael R. 2005. "Dealing with a Truculent Ally: A Comparative Perspective on China's Handling of North Korea." Journal of East Asian Studies 5, 1: 35-75.

Chen, Jian. 2001. Mao China and the Cold War. Chapel Hill: University of North Carolina Press.

Chung Jae Ho. 2007. Between Ally and Partner: Korea-China Relations and the United States. New York: Columbia University Press.

Goldstein, Avery. 2006. "Across the Yalu: China's Interests and the Korean Peninsula in a Changing World." In New Directions in the Study of China's Foreign Policy, ed. Alastair Iain Johnston and Robert Ross. Palo Alto: Stanford University Press.

Gong, Gerrit. 1984. The Standard of “Civilization” in International Society. Oxford: Clarendon Press.

Gries, Peter Hays. 2005a. “China's 'New Thinking' on Japan.” China Quarterly 184: 831-850.

- 2005b. "The Koguryo Controversy, National Identity, and Sino-Korean Relations Today.” East Asia: An International Quarterly 22, 4: 3-17. 
International Crisis Group. 2011. "China and Inter-Korean Clashes in the Yellow Sea." Asia Report No. 200.

Kim, Samuel. 2004. "China's New Role in the Nuclear Confrontation." Asian Perspective 28, 4: 147-184.

Kline, Rex B. 2005. Principles and Practice of Structural Equation Modeling. 2nd ed. New York: Guilford.

Larsen, Kirk W. 2008. Tradition, Treaties, and Trade: Qing Imperialism and Chosun Korea, 1850-1910. Cambridge: Harvard University Press.

Madsen, Richard. 1995. China and the American Dream. Berkeley: University of California Press.

Mann, James. 1998. About Face: A History of America's Curious Relationship with China, From Nixon to Clinton. New York: Knopf.

Qian Qichen. 2005. Ten Episodes in China's Diplomacy. New York: HarperCollins.

Russell, Daniel W. 2002. "In Search of Underlying Dimensions: The Use (and Abuse) of Factor Analysis in Personality and Social Psychology Bulletin." Personality and Social Psychology Bulletin 28, 12: 1629-1646.

Shambaugh, David. 2003. "China and the Korean Peninsula: Playing for the Long Term." Washington Quarterly 26, 2: 43-56.

Shen Dingli. 2006. "North Korea's Strategic Significance to China." China Security 4: 19-34.

Shen Jiru, 2003. "The Urgent Task of Maintaining Security in Northeast Asia: How to Stop the Dangerous Games in the DPRK's Nuclear Crisis." Shijie jingji yu zhengzhi [World Economics and Politics] 9: 53-58.

Snyder, Scott. 2009. China's Rise and the Two Koreas: Politics, Economics, Security. Boulder: Lynne Rienner.

Time. 1985. "Person of the Year." Available at www.time.com/time/subscriber/ personoftheyear/archive/stories/1985.html (accessed June 1, 2007).

Tkacik, John. 2006. "How the PLA Sees North Korea." In Shaping China's Security Environment: The Role of the People's Liberation Army, ed. Andrew Scobell and Larry M. Wortzel. Carlisle, PA: Strategic Studies Institute, US Army War College.

Zhang Liangui. 2006. "Coping with a Nuclear North Korea." China Security 4: 2-18.

Zhu Feng. 2006. "Shifting Tides: China and North Korea." China Security 4: 35-50. 